\title{
INFRARED ABSORPTION AND STRUCTURES OF BORATE POLYATOMIC IONS
}

\author{
YoshIO TAKÉUCHI \\ Mineralogical Institute, University of Tokyo
}

\begin{abstract}
The infrared absorption spectra of selected borate minerals have been observed with crystalline powders in the wavelength range from 2 to 16 microns. The spectra characteristic to borate polyatomic ions appear within the range from 7 to 16 microns and are presented in Figs. 1-6. These characteristic absorption bands are shown to be useful in the qualitative analysis of borate polyatomic ions.

In connection with this investigation, a discussion on the structures of borate polyatomic ions is also given.
\end{abstract}

\section{Introduction}

While examining the infrared absorption spectra of szaibelyite, $\mathrm{MgHBO}_{3}$, for the purpose of investigating the state of hydrogen in the structure, fairy well defined absorption spectra were obtained in the wavelength range from 7 to 16 microns. It is obvious that these spectra in this range are due to the 'internal' vibrations of borate polyatomic ions in the structure of szaibelyite. A check shows that the absorption spectra are quite different from those previously reported of other borates such as boric acid or boraxi1). It appears therefore, that borate polyatomic ions possess frequencies which are sufficiently chracteristic to be useful for analytical purposes. Although extensive surveys of infrared absorption spectra of inorganic ions have been made ${ }^{8) 11}$ and it has been proved that they are potentially useful for analytical use, the study on the borates of mineralogical importance has been neglected. It therefore seemed worth while to examine the infrared absorption spectra of thess borate minerals.

If the correlation between the infrared absorption spectra and the 
structural types of borate polyatomic ions is made clear, it might well be possible to predict the structural types of polyătomic ions in borates whose crystal structures are unknown. This paper presents the spectra of 17 pure borate minerals and shows the relations between the spectra and structural types of borate polyatomic ions whose structures have so far been determined. Finally, the structures of borate polyatomic ions are discussed.

\section{Experimental}

Materials.

The samples used for the present investigation are listed below.

\begin{tabular}{lll}
\multicolumn{1}{c}{ Sample } & \multicolumn{1}{c}{$\begin{array}{c}\text { State of sample } \\
\text { coarse powder }\end{array}$} & \multicolumn{1}{c}{ Origin } \\
kotoite & artificial \\
ludwigite & frous crystal & Suan Mine, Korea \\
pinakiolite & crystal & Langban, Sweden \\
suanite & fibrous crystal & Suan Mine, Korea \\
camsellite & matted fibrous & Douglas Lake, B. C. \\
sussexite & fibrous crystal & Sussex Co., N. J. \\
colemanite & crystal & Death Valley, Calif. \\
lesserite & crystal & Kern Co., Calif. \\
inderite & crystal & Kern Co., Calif. \\
meyerhofferite & crystal & Death Valley, Calif. \\
hilgardite & crystal & Iberville Parish, Louis. \\
ulexite & crystal & Ryan, Calif. \\
priceite & powder & Curry Co., Oregon \\
probertite & crystal & Kern Co., Calif. \\
kernite & crystal & Kern Co., Calif. \\
pinnoite & crystal & Stassfurt, Saxony \\
boron oxide & coarse powder & artificial
\end{tabular}

The samples obtained in well developed pure crystals were of highest purity. Other samples, especially, camsellite, priceite and pinnoite were carefully separated and examined under the microscope and by X-ray powder method and those of high purity were chosen for the infrared examination.

Spectroscopic procedures.

The samples were ground to fine powder to minimize the scat- 
tering of light and rubbed between salt plates. All data were obtained on a Hilgar $\mathrm{H} 800$ spectrometer, with a rock salt prism, using Nujol as the mounting medium. The region from 2 to 16 microns was scanned. No attempt was made to put the spectra on a quantitative basis which may not be necessary for the present purposes.

\section{Results}

The spectra in the wavelength range from 7 to 16 microns are shown in Figs. 1 6. The range well covers the characteristic absorption spectra of borate polyatomic ions. Some of the borate bands might exist in the regions of Nujol bands, however it does not limit the purpose of the present investigation. Fig. 8 sumarizes the positions of the spectra in wave numbers and gives roughly estimated peak intensities.

The absorption spectra of hydroxyl and water molecules are in the wavelength range from 2 to 7 microns. Although the interpretation of these spectra might give an interesting knowledge on the state of hydrogen atoms in the structures of hydrated borates, this is beyond the scope of the present work. However, some of them are shown in Fig. 7 .

Absorption spectra of $\mathrm{BO}_{3}$ groups.

$\mathrm{BO}_{3}$ groups present most simple spectra and are well studied in the crystalline boric acid 7 and other simple orthoboratesi4). The absorption peak due to the fundamental modes such as totally symmetric stretch, $\omega_{1}$ and out-of-plane bend, $\omega_{2}$, are most characteristic for the group. The frequencies of these absorption peaks observed for kotoite, ludwigite and pinakiolite are as follows:

$\begin{array}{lcc} & \omega_{1}\left(\mathrm{~cm}^{-1}\right) & \omega_{2}\left(\mathrm{~cm}^{-1}\right) \\ \text { kotoite } & 905 & 720 \\ \text { ludwigite } & 880 & 720 \\ \text { pinakiolite } & 850 & 720\end{array}$

The degenerate stretch, $\omega_{3}$, gives very broad intense absorption peaks 

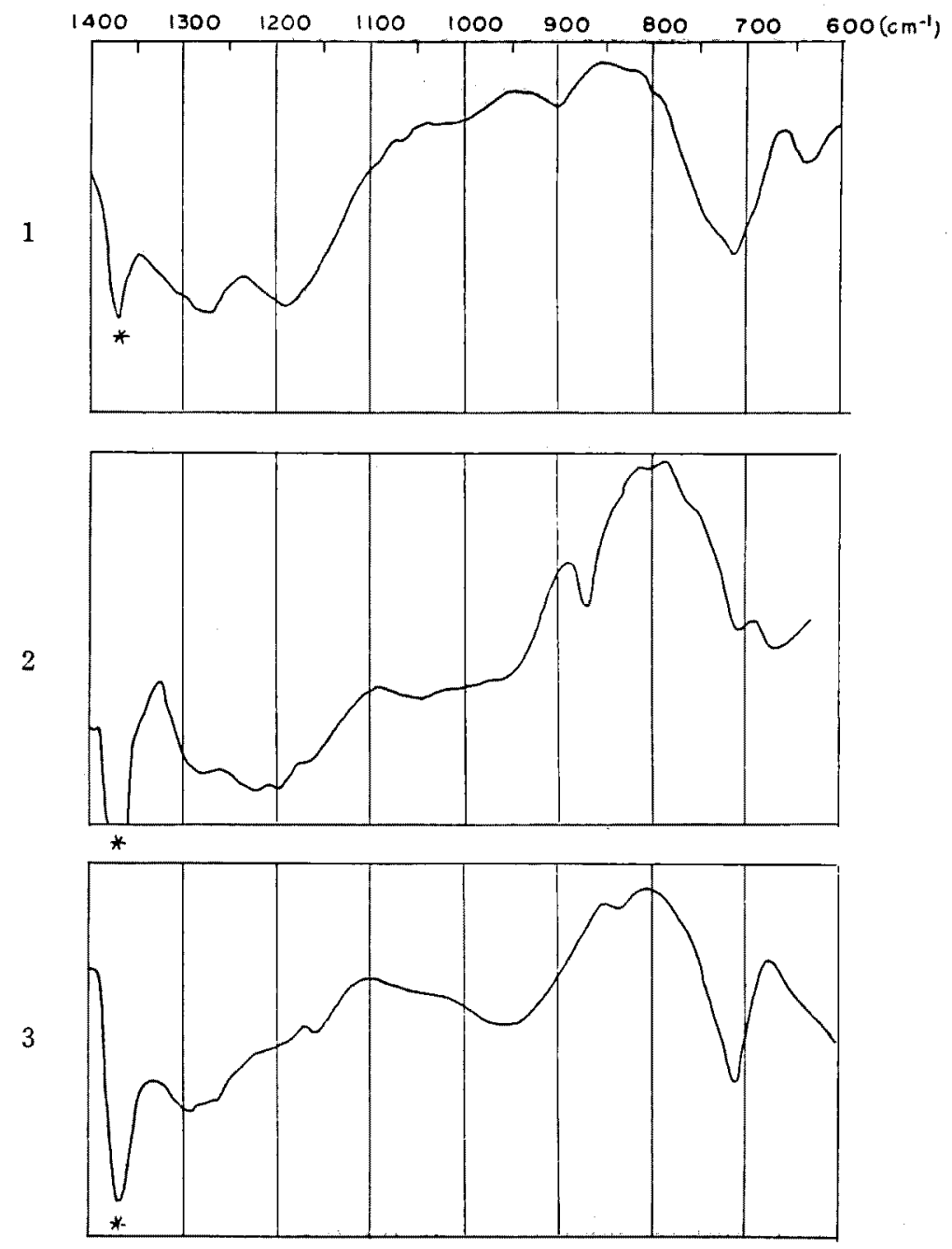

Fig. 1 Infrared absorption spectra of orthoborates.

1. kotoite, $\mathrm{Mg}_{2}\left(\mathrm{BO}_{3}\right)_{2}$

2. ludwigite, $2 \mathrm{MgOFe}{ }^{3}+\mathrm{BO}_{3}$

3. pinakiolite. $2 \mathrm{MgOMn}^{3}+\mathrm{BO}_{3}$ 

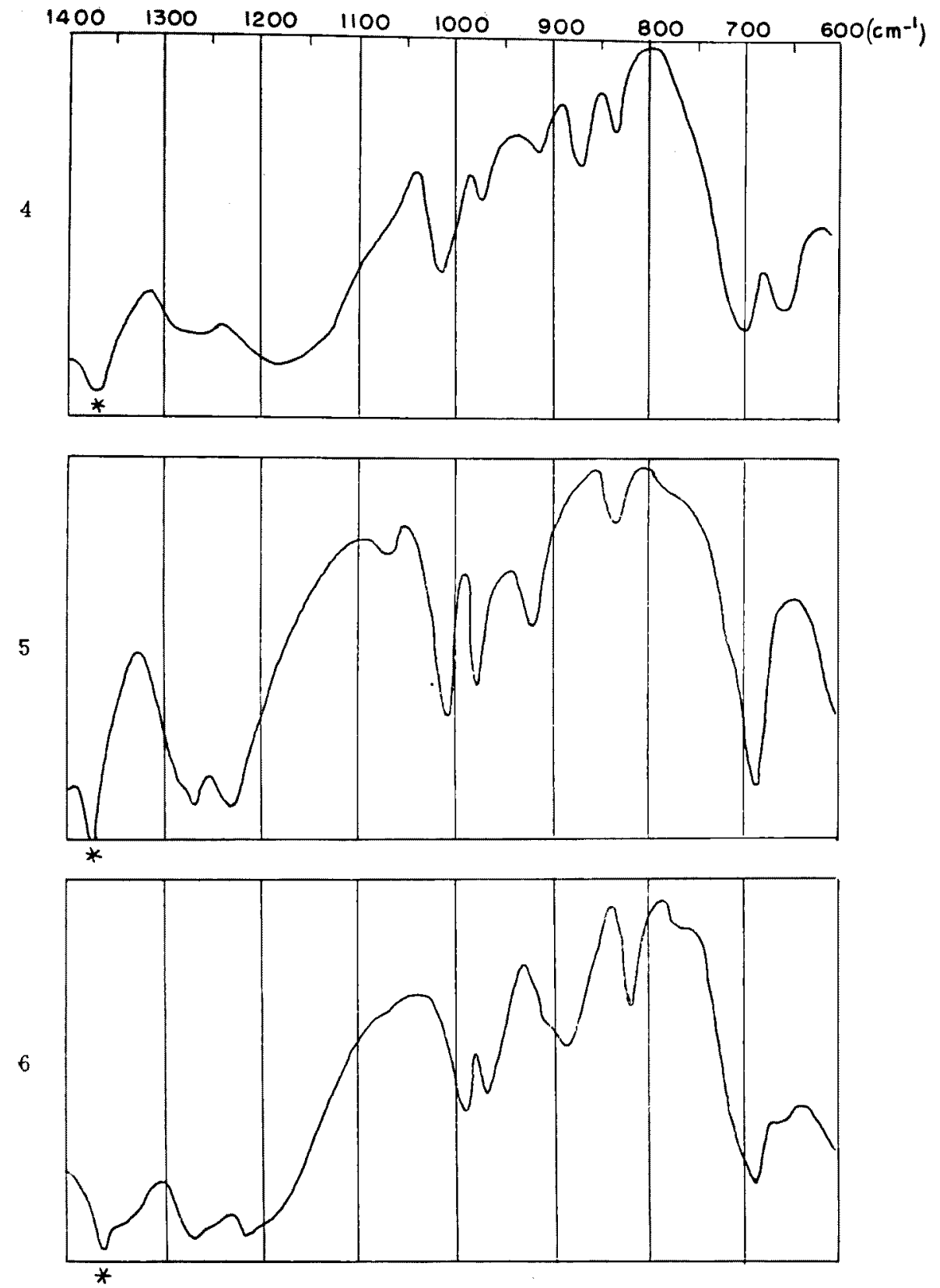

Fig. 2 Infrared absorption spectra of pyrborates with triangular configurations. 4. suanite, $\mathrm{Mg}_{2} \mathrm{~B}_{2} \mathrm{O}_{3}$ 6. sussexite, $\mathrm{MnHBO}_{3}$

5. camsellite, $\mathrm{MgHBO}_{3}$ 

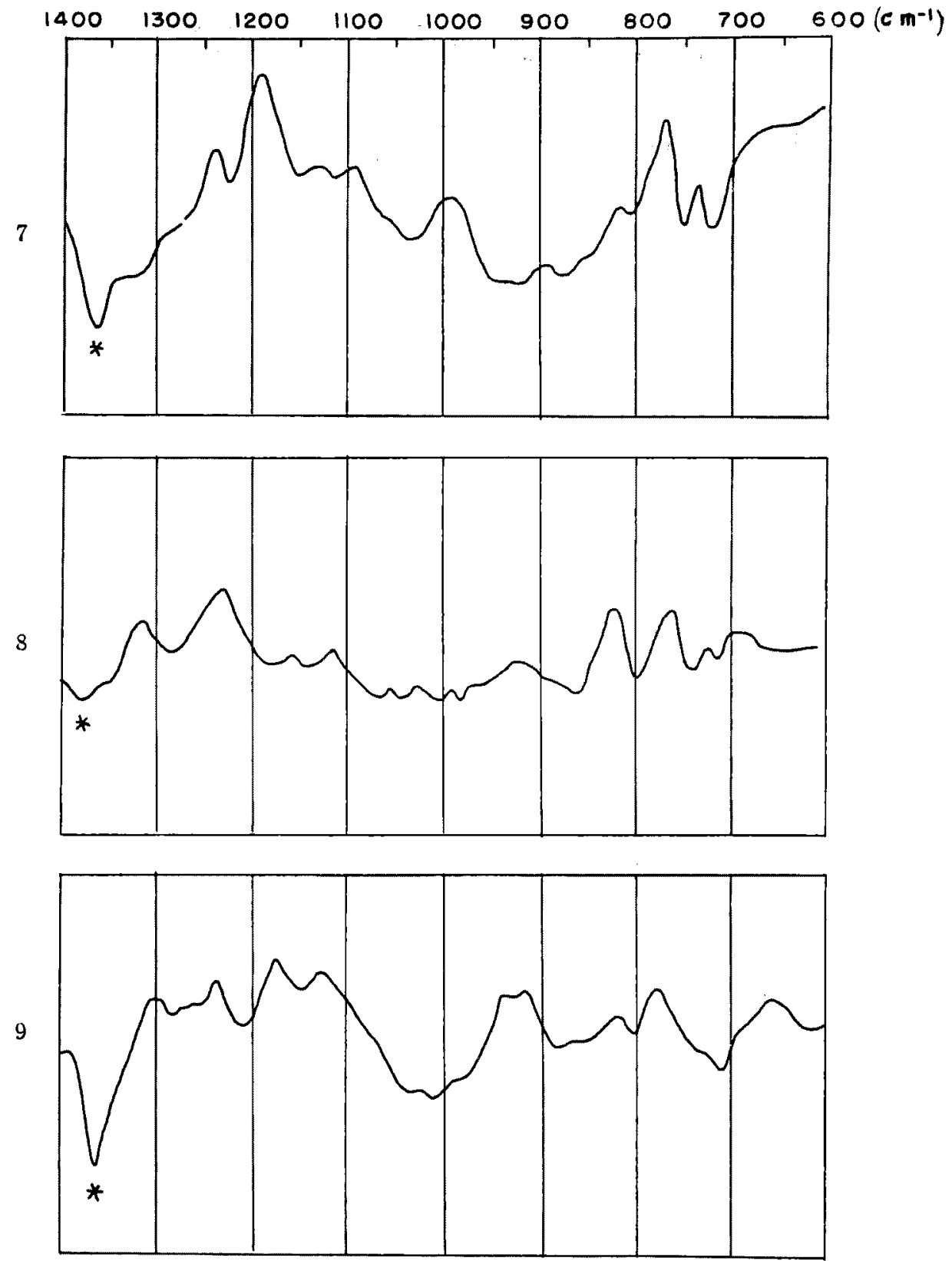

Fig. 3 Infrared absorption spectra cf borates.

7. colemanite, $\mathrm{CaH}_{3} \mathrm{~B}_{3} \mathrm{O}_{7} \cdot \mathrm{H}_{2} \mathrm{O}$ 8. lesserite, $\mathrm{Mg}_{2} \mathrm{~B}_{6} \mathrm{O}_{11} \cdot 15 \mathrm{H}_{2} \mathrm{O}$

9. inderite, $\mathrm{Mg}_{2} \mathrm{~B}_{6} \mathrm{O}_{11} \cdot 15 \mathrm{H}_{2} \mathrm{O}$ 

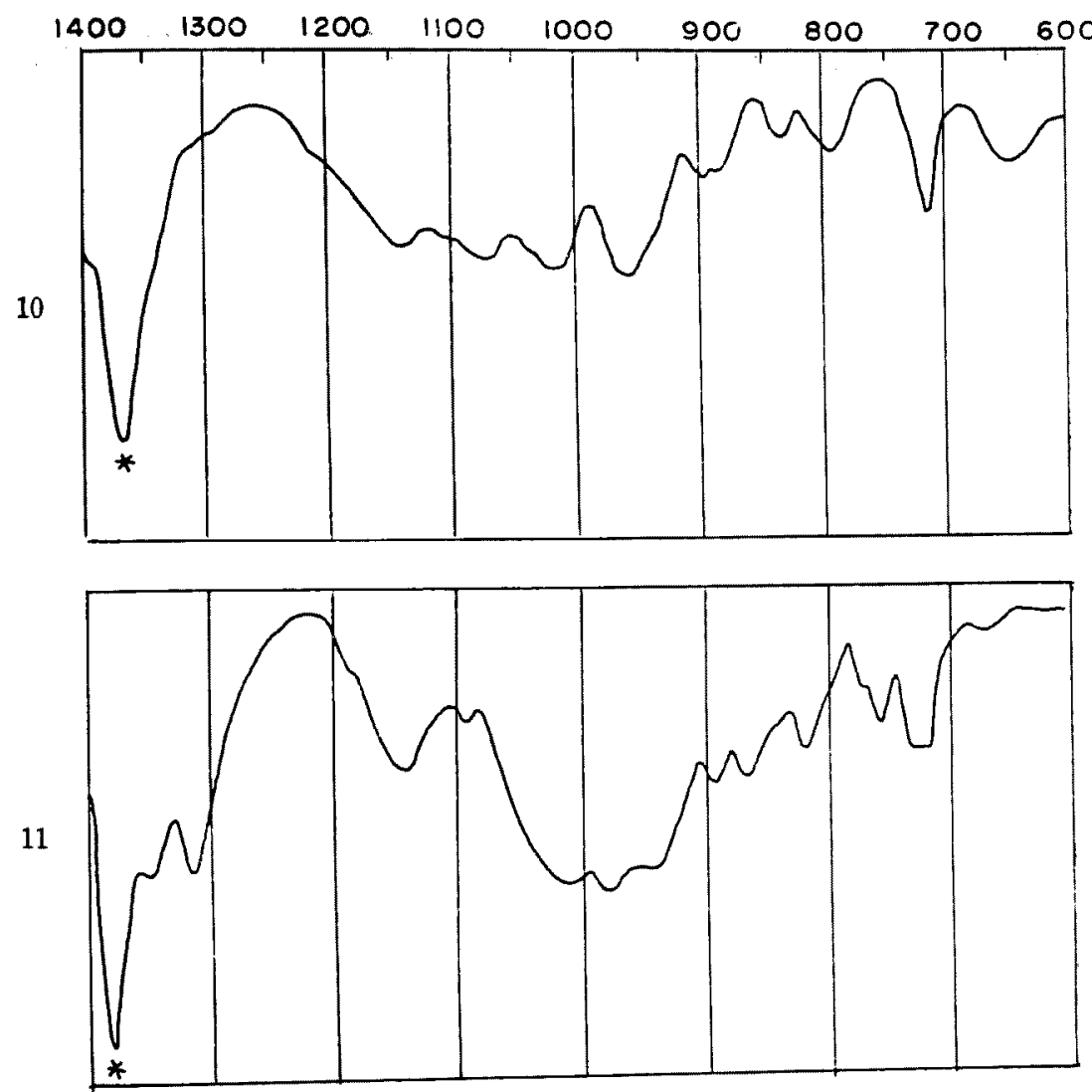

12

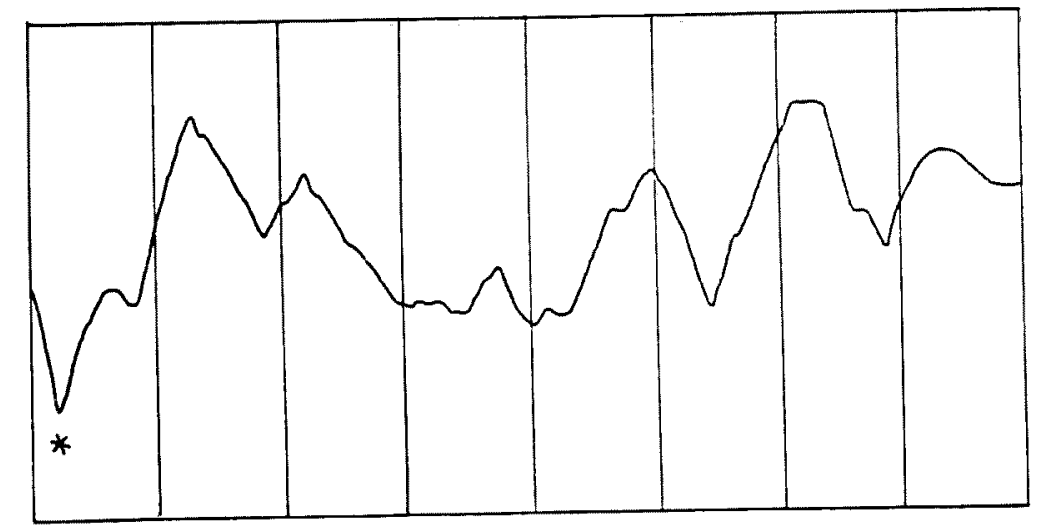

Fig. 4 Infrared absorption spectra of borates.

10. meyerhofferite, $\mathrm{CaH}_{5} \mathrm{~B}_{3} \mathrm{O}_{8} \cdot \mathrm{H}_{2} \mathrm{O}$ 11. hilgardite, $\mathrm{Ca}_{8}\left(\mathrm{~B}_{6} \mathrm{O}_{11}\right)_{3} \mathrm{Cl}_{4} \cdot 4 \mathrm{H}_{2} \mathrm{O}$ 12. ulexite, $\mathrm{NaCaB}_{5} \mathrm{O}_{9} \cdot 8 \mathrm{H}_{2} \mathrm{O}$ 
252 Infrared Absorption and Structures of Borate Polyatomic lons

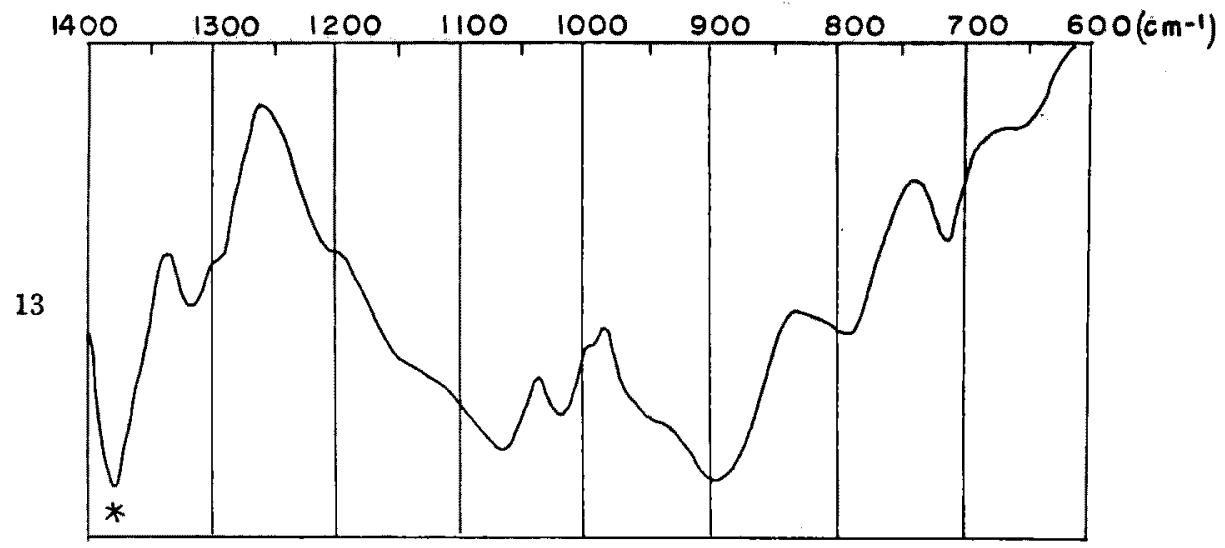

14

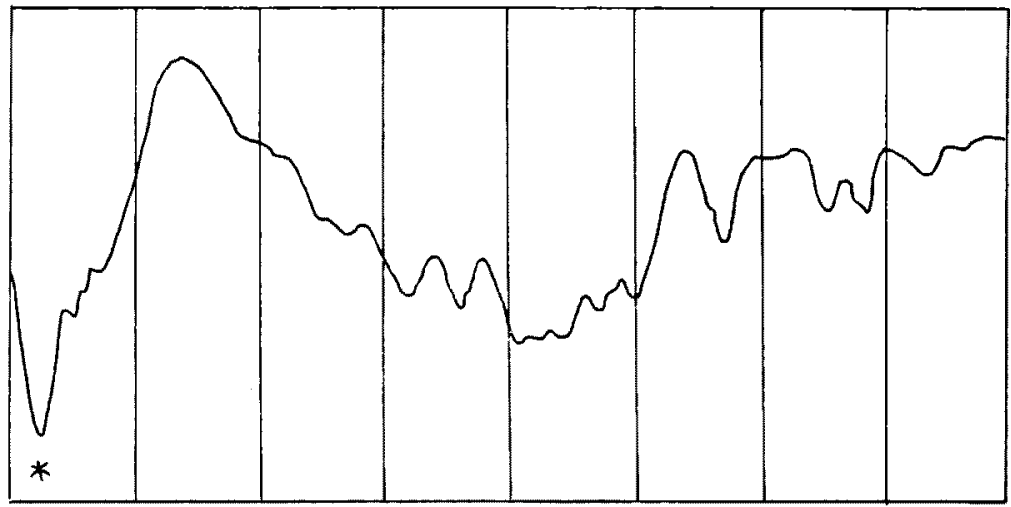

15

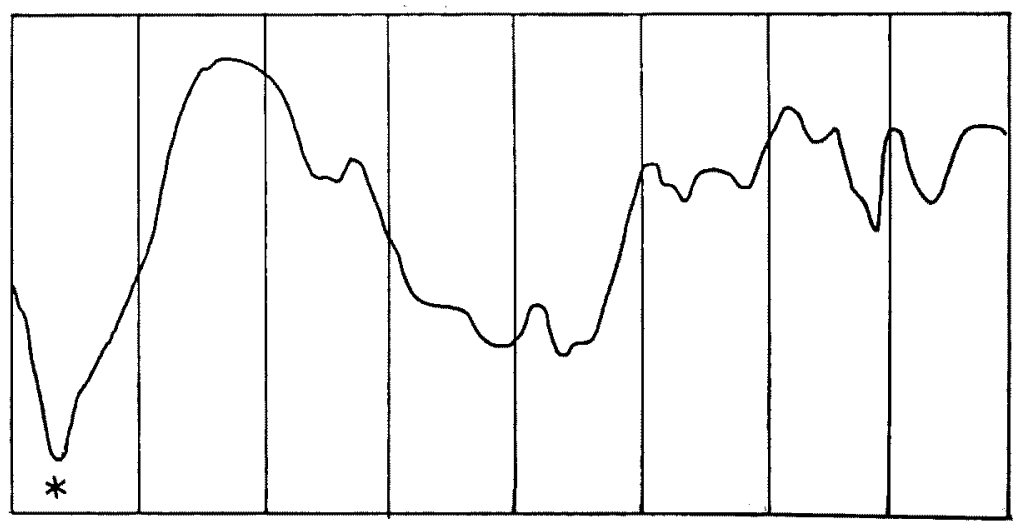

Fig. 5 Infrared absorption spectra of borates.

13. priceite, $\mathrm{Ca}_{4} \mathrm{~B}_{10} \mathrm{O}_{19} \cdot 7 \mathrm{H}_{2} \mathrm{O}$

15. kernite, $\mathrm{Na}_{2} \mathrm{~B}_{4} \mathrm{O}_{7} \cdot 4 \mathrm{H}_{2} \mathrm{O}$

14. probertite, $\mathrm{NaCaB}_{5} \mathrm{O}_{9} \cdot 5 \mathrm{H}_{2} \mathrm{O}$ 
around $1250 \mathrm{~cm}^{-1}$.

It should be noted that totally symmetric stretch, $\omega_{1}$, becomes. inactive for some particular site symmetry of the $\mathrm{BO}_{3}$ group ${ }^{7)}$. The frequency difference as observed in these minerals may be due to the difference of the surrounding atoms of $\mathrm{BO}_{3}$ groups in these structures $^{\text {9)19) 20). }}$.

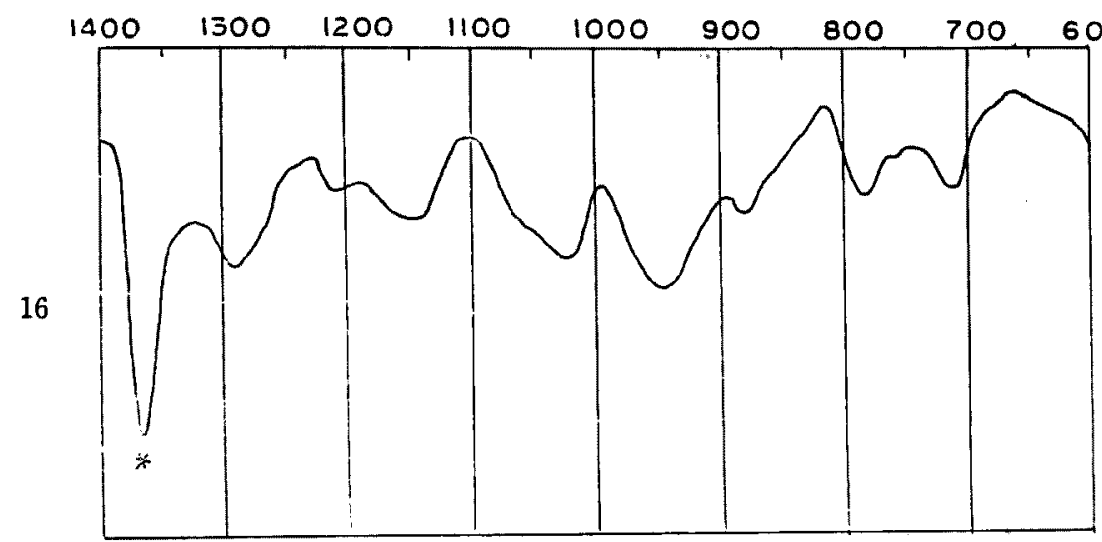

17

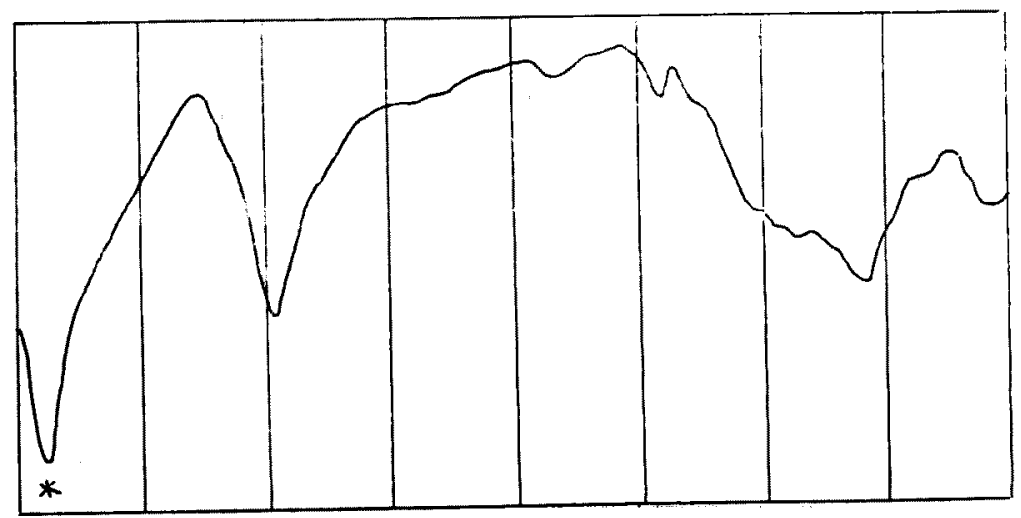

Fig. 6 Infrared absorption spectra of borate poylatomic ions with tetrahedral configurations.

16. pinnoite, $\mathrm{MgH}_{6} \mathrm{~B}_{2} \mathrm{O}_{7}$

17. boron oxide, $\mathrm{B}_{2} \mathrm{O}_{3}$

Nujol bands are marked with asterisks throughout Figs. 1-7. 
Absorption spectra of $\mathrm{B}_{2} \mathrm{O}_{5}$ groups.

Suanite which contains $\left(\mathrm{B}_{2} \mathrm{O}_{5}\right)$ groups presents well defined absorption peaks which are so characteristic that they are easily distinguished from those of the other borate polyatomic ions. It seems that the $\left(B_{2}\right.$

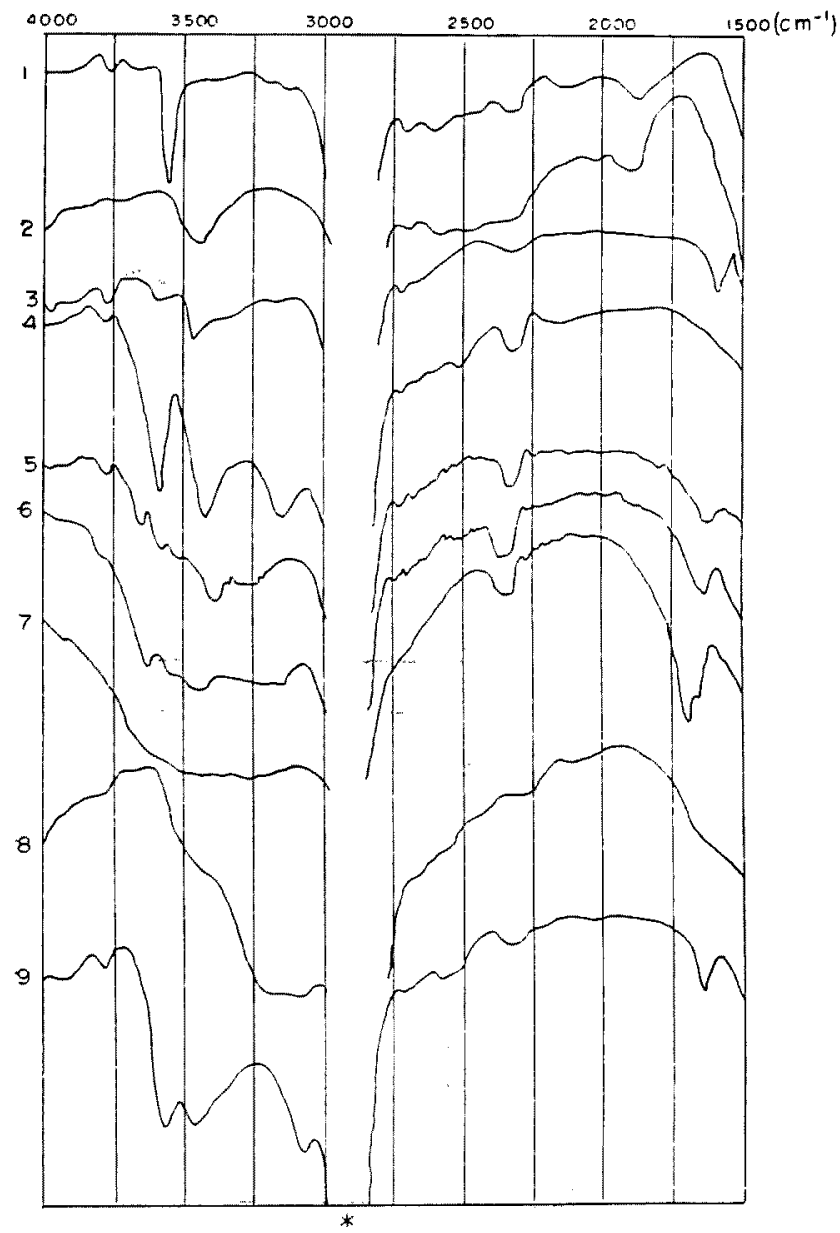

Fig. 7 Infrared absorption spectra of borates in the frequency range $4000-1500 \mathrm{~cm}^{-1}$.
1. camsellite
2. sussexite
3. hilgardite
4. pinnoite
5. probertite
6. ulexite
7. lesserite
8. colemanite
9. priceite 
$\mathrm{O}_{5}$ ) groups exist not only in this rare mineral but also in camsellite (szaibelyite) and sussexite, because the absorption spectra of these minerals show striking similarity with those of suanite.

In this view point, the chemical formula of camsellite and sussexite may be expressed as $\mathrm{H}_{2} \mathrm{Mg}_{2} \mathrm{O}\left(\mathrm{B}_{2} \mathrm{O}_{5}\right)$ and $\mathrm{H}_{2} \mathrm{Mn}_{2} \mathrm{O}\left(\mathrm{B}_{2} \mathrm{O}_{5}\right)$ respectively. Thus, the unit cells of these borates contain four of these chemical units16). The extreme fibrous nature of these borates will be based upon a chain linkage of $\mathrm{MgO}_{6}$ or $\mathrm{MnO}_{6}$ octahedra as in magnesium orthoborates ${ }^{17) 19)}$ or in suanite ${ }^{18)}$.

The frequencies of absorption spectra of suanite, camsellite and sussexite are compared in Table 1 together with estimated peak intensities.

Table 1. Infrared absorption spectra of pyroborates with triangular configurations.

\begin{tabular}{|c|c|c|c|c|c|c|}
\hline \multicolumn{2}{|r|}{ suanite } & \multicolumn{2}{|r|}{ camsellite } & \multicolumn{3}{|c|}{ sussexite } \\
\hline \multicolumn{2}{|r|}{$\mathrm{Mg}_{2} \mathrm{~B}_{2} \mathrm{O}_{5}$} & \multicolumn{2}{|r|}{$\mathrm{MgHBO}_{3}$} & \multicolumn{3}{|c|}{$\mathrm{MnHBO}_{3}$} \\
\hline \multirow[t]{3}{*}{$I$} & Frequency $(\mathrm{cm}-1)$ & $I \quad 1$ & Frequency $\left(\mathrm{cm}^{-1}\right)$ & $I$ & \multicolumn{2}{|c|}{ Frequency $\left(\mathrm{cm}^{-1}\right)$} \\
\hline & & $\mathrm{m}$ & 3552 & $\mathrm{~m}$ & 3460 & \\
\hline & & $\mathrm{w}$ & 1900 & $\mathrm{w}$ & 1900 & \\
\hline $\mathbf{s}$ & $1275 \mathrm{~b}$ & $\mathrm{~s}$ & 1270 & s & $1270 \mathrm{~b}$ & \\
\hline s & $1180 \mathrm{~b}$ & $s$ & 1230 & s & $1210 \mathrm{~b}$ & \\
\hline$w$ & $1075 \mathrm{sh}$ & $w$ & 1075 & & & \\
\hline $\mathrm{m}$ & 1019 & $\mathrm{~m}$ & 1010 & $\mathrm{~m}$ & 992 & \\
\hline $\mathrm{w}$ & 976 & $\mathrm{~m}$ & 979 & $\mathrm{~m}$ & 970 & $\left(\mathrm{~B}_{2} \mathrm{O}_{5}\right)$ \\
\hline$w$ & 921 & $\mathrm{~m}$ & 921 & & 910 & $\left(x_{2}\right)$ \\
\hline $\mathrm{m}$ & 872 & vw & $880 \mathrm{sh}$ & 111 & $885^{\mathrm{D}}$ & spectra \\
\hline $\mathrm{m}$ & 839 & $w$ & 830 & $\mathrm{~m}$ & 828 & \\
\hline & & vw & .775 & vw & 770 & \\
\hline s & 705 & s & 690 & $\mathrm{~s}$ & 695 & \\
\hline s & 665 & & & $s$ & 660 & \\
\hline
\end{tabular}

sh = shoulder $\quad b=$ broad. 
Absorption spectra of other borate polyatomic ions with triangular configurations.

In addition to the above groups, $\left(\mathrm{B}_{2} \mathrm{O}_{4}\right)$ chain and $\left(\mathrm{B}_{3} \mathrm{O}_{6}\right)$ ring structures are also known as with triangular configurations ${ }^{21}{ }^{25}$ ). The absorption spectra of the latter have been reported by F. A. Miller and C. H. Wilkins ${ }^{11)}$, strong peaks of frequency $925 \mathrm{~cm}^{-1}, 1310 \mathrm{~cm}^{-1}$ and medium $1175 \mathrm{~cm}^{-1}$, weak $862 \mathrm{~cm}^{-1}$ peaks being characteristic to the group. The spectra of $\left(\mathrm{B}_{2} \mathrm{O}_{4}\right)$ chain structure were not obtained because of the difficulty of preparing crystals which contain this boronoxygen linkage.

Table 2. Infrared absorption spectra of pinnoite.

\begin{tabular}{|c|c|c|}
\hline$I$ & Frequency & $\left(\mathrm{cm}^{-1}\right)$ \\
\hline $\mathrm{s}$ & 3610 & \multirow{3}{*}{$(\mathrm{OH})$} \\
\hline s & 3440 & \\
\hline s & 3175 & \\
\hline $\mathrm{s}$ & 1290 & \multirow{10}{*}{$\left(\mathrm{B}_{3} \mathrm{O}_{7}\right)$} \\
\hline $\mathrm{w}$ & 1220 & \\
\hline $\mathrm{m}$ & 1150 & \\
\hline $\mathrm{m}$ & 1070 & \\
\hline s & 1030 & \\
\hline $\mathrm{s}$ & 960 & \\
\hline $\mathrm{m}$ & 895 & \\
\hline $\mathrm{w}$ & 800 & \\
\hline $\mathrm{w}$ & 760 & \\
\hline w & 720 & \\
\hline
\end{tabular}

Absorption spectra of borate polyatomic ions with tetrahedral configuretions.

Pinnoite $\mathrm{Mg}\left(\mathrm{BO}_{2}\right)_{2} \cdot 3 \mathrm{H}_{2} \mathrm{O}$ has $\left(\mathrm{B}_{2}\right.$ $\mathrm{O}_{7}$ ) polyatomic ions which consist of two $\mathrm{BO}_{4}$ tetrahedra having one oxygen in common ${ }^{13)}$. The infrared absorption spectra of pinnoite are shown in Fig. 6. Frequencies of the observed peaks are given in Table 2.

The borates which contain separrate $\mathrm{BO}_{4}$ tetrahedra are rare. Teepleite, $\mathrm{Na}_{2} \mathrm{H}_{4}\left(\mathrm{BO}_{4}\right) \mathrm{Cl}$, would perhaps be the only one suitable to obtain the infrared data of $\mathrm{BO}_{4}$ tetrahedron.

Absorption spectra of borate polyatomic ions with hybrid configurations.

The hybrid configuration which consists of a $\mathrm{BO}_{3}$ triangle and a $\mathrm{BO}_{4}$ tetrahedron (Fig. 9) is the most interesting subject in the studies. of borate polyatomic ions. $\left(\mathrm{B}_{4} \mathrm{O}_{9}\right)$ and $\left(\mathrm{B}_{3} \mathrm{O}_{8}\right)$ groups and $\left(\mathrm{B}_{3} \mathrm{O}_{7}\right)$ chain structures found in borax ${ }^{12)}$, meyerhofferite ${ }^{4)}$ and colemanite 3 respective- 
ly are built of these cofigurations. The infrared spectra of these minerals are shown in Figs. 3 and 4.

Although the infrared peaks of these complicated borate polyatomic ions are not so well defined as those of simpler borate groups, they are still characteristic enough for analytical use. For instance, potassium tetraborate, $\mathrm{K}_{2} \mathrm{~B}_{4} \mathrm{O}_{2} \cdot 5 \mathrm{H}_{2} \mathrm{O}$, presents very similar spectra with those of borax ${ }^{11}$. It therefore seems probable that the crystal will contain $\left(\mathrm{B}_{4} \mathrm{O}_{9}\right)$ groups rather than ' $\left(\mathrm{B}_{4} \mathrm{O}_{7}\right)$ ions' which has often been conceived by chemists. Thus the chemical formula of the substance may be written as $\mathrm{K}_{2} \mathrm{H}_{4} \mathrm{~B}_{4} \mathrm{O}_{9} \cdot 3 \mathrm{H}_{2} \mathrm{O}$.

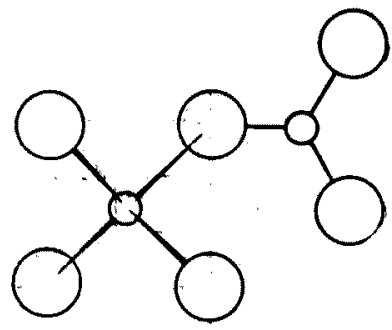

Fig. 9 Hybrid configuration of boron-oxygen arrangement.

As shown in Fig. 8 in the form of a line graph, the similarity of the spectra also suggests that inderite, $\mathrm{Mg}_{-} \mathrm{B}_{6} \mathrm{O}_{\mathrm{I}} \cdot 15 \mathrm{H}_{2} \mathrm{O}$, is probably built up with $\left(\mathrm{B}_{3} \mathrm{O}_{8}\right)$ polyatomic ions as meyerhofferite. For lesserite, the monoclinic polymorph of inderite ${ }^{6}$, its spectra are analogous, in some ways, to those of colemanite but also similar to those of meyerhofferite. Therefore, no definite conclusion can be drawn for this case.

\section{Borate polyatomic ions}

Inspite of the formal analogy that $\left(\mathrm{B}_{3} \mathrm{O}_{6}\right)$ rings and $\left(\mathrm{B}_{2} \mathrm{O}_{4}\right)$ chains contained in most of metaborates correspond to $\left(\mathrm{Si}_{3} \mathrm{O}_{9}\right)$ rings and $\left(\mathrm{SiO}_{3}\right)$ chains in metasilicates, the following two points may be mentioned as the characteristic differences between boron-oxygen arrangements and silicon-oxygen arrangements; Firstly, boron atoms may have either triangular or tetrahedral coordination and secondly, the bonds between boron and oxygen are less ionic than those between silicon and oxygen.

The partial ionic character for $\mathrm{B}-\mathrm{O}$ and $\mathrm{Si}-\mathrm{O}$ bonds may be estimated from the differences of electron negativity of these atoms. They are found as follows: 
258 Infrared Absorption and Structures of Borate Polyatomic Ions

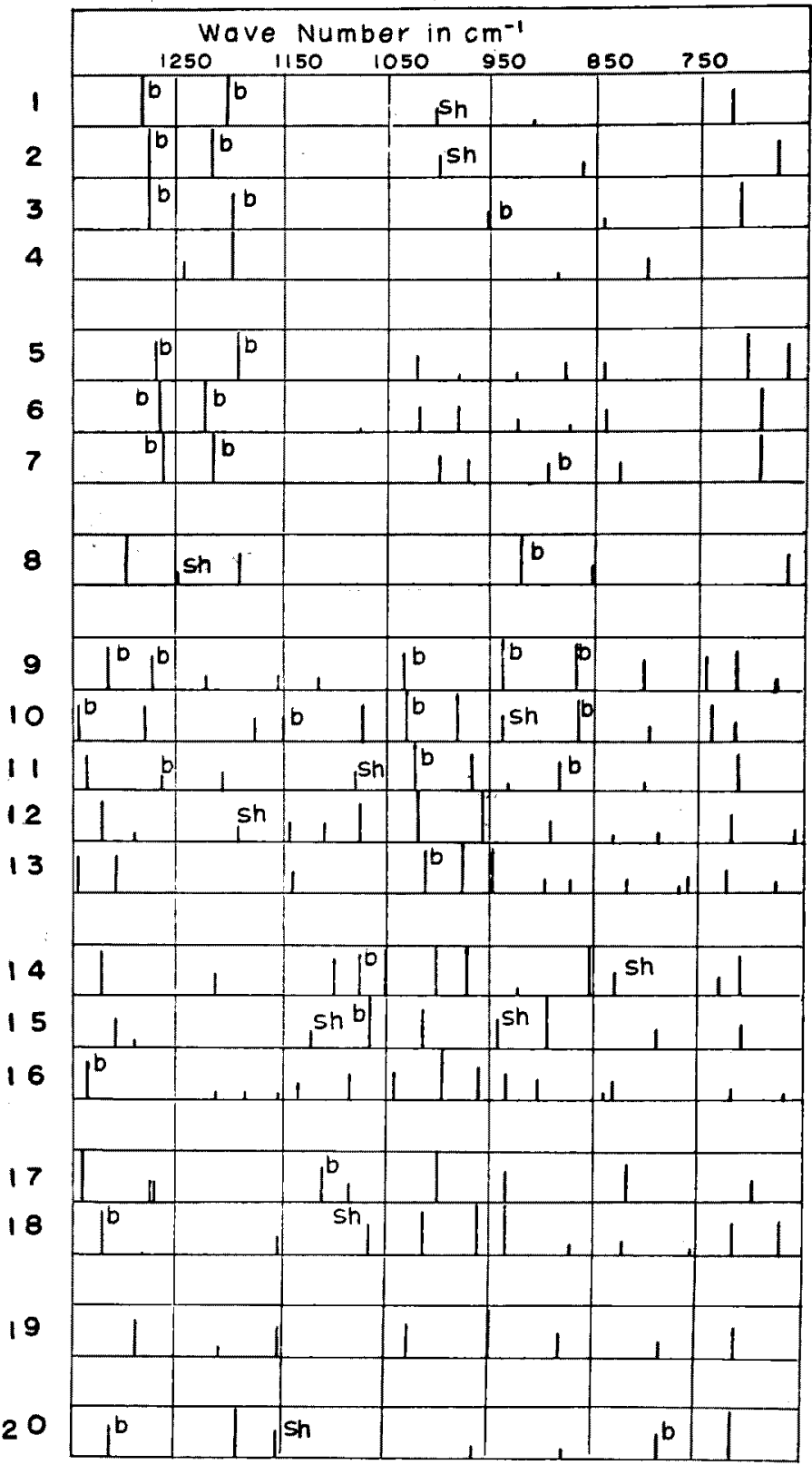

Fig. 8 Comparison of infrared spectra of borates. Positions of absorption spectra and estimated intensities are given. 
Table for the explanation of Fig. 8 .

\begin{tabular}{|c|c|c|c|}
\hline & Substance & empirical formula & structural formula \\
\hline 1. & kotoite & $\mathrm{Mg}_{3} \mathrm{~B}_{2} \mathrm{O}_{6}$ & $\mathrm{Mg}_{3}\left(\mathrm{BO}_{3}\right)_{2}$ \\
\hline 2. & ludwigite & $2 \mathrm{MgOFe}_{2} \mathrm{O}_{3} \mathrm{~B}_{2} \mathrm{O}_{3}$ & $2 \mathrm{MgOFe}^{8+\mathrm{BO}_{3}}$ \\
\hline 3. & pinakiolite & $2 \mathrm{MgOMn}{ }_{2} \mathrm{O}_{3} \mathrm{~B}_{2} \mathrm{O}_{3}$ & $2 \mathrm{MgOMn}^{3}+\mathrm{BO}_{3}$ \\
\hline 4. & *boric acid & $\mathrm{H}_{3} \mathrm{BO}_{3}$ & $\mathrm{H}_{3} \mathrm{BO}_{3}$ \\
\hline 5. & suanite & $2 \mathrm{MgOB}_{2} \mathrm{O}_{3}$ & $\mathrm{Mg}_{2} \mathrm{~B}_{2} \mathrm{O}_{5}$ \\
\hline 6. & camsellite & $\mathrm{MgHBO}_{3}$ & \\
\hline 7. & sussexite & $\mathrm{MnHBO}_{3}$ & \\
\hline 8. & *sodium metaborate & $\mathrm{NaBO}_{2}$ & $\mathrm{Na}_{3} \mathrm{~B}_{3} \mathrm{O}_{6}$ \\
\hline 9. & colemanite & $\mathrm{Ca}_{3} \mathrm{~B}_{6} \mathrm{O}_{11} 5 \mathrm{H}_{2} \mathrm{O}$ & $\mathrm{CaH}_{3} \mathrm{~B}_{3} \mathrm{O}_{7} \cdot \mathrm{H}_{2} \mathrm{O}$ \\
\hline 10. & lesserite & $\mathrm{Mg}_{3} \mathrm{~B}_{6} \mathrm{O}_{11} \cdot 15 \mathrm{H}_{2} \mathrm{O}$ & \\
\hline 11. & inderite & $\mathrm{Mg}_{2} \mathrm{~B}_{0} \mathrm{O}_{11} \cdot 15 \mathrm{H}_{2} \mathrm{O}$ & \\
\hline 12. & meyerhofferite & $\mathrm{Ca}_{3} \mathrm{~B}_{6} \mathrm{O}_{11} \cdot 7 \mathrm{H}_{2} \mathrm{O}$ & $\mathrm{CaH}_{5} \mathrm{~B}_{3} \mathrm{O}_{8} \cdot \mathrm{H}_{2} \mathrm{O}$ \\
\hline 13. & hilgardite & $\mathrm{Ca}_{3}\left(\mathrm{~B}_{6} \mathrm{O}_{11}\right)_{3} \mathrm{Cl}_{4} \cdot 4 \mathrm{H}_{2} \mathrm{O}$ & \\
\hline 14. & ulexite & $\mathrm{NaCaB}_{\overline{0}} \mathrm{O}_{9} \cdot 8 \mathrm{H}_{\varepsilon} \mathrm{O}$ & \\
\hline 15. & priceite & $\mathrm{Ca}_{1} \mathrm{~B}_{10} \mathrm{O}_{19} \cdot 7 \mathrm{H}_{2} \mathrm{O}$ & \\
\hline 16. & probertite & $\mathrm{NaCaB}_{3} \mathrm{O}_{9} \cdot 5 \mathrm{H}_{2} \mathrm{O}$ & \\
\hline 17. & *borax & $\mathrm{Na}_{2} \mathrm{~B}_{4} \mathrm{O}_{7} \cdot 10 \mathrm{H}_{2} \mathrm{O}$ & $\mathrm{Na}_{2} \mathrm{H}_{4} \mathrm{~B}_{4} \mathrm{O}_{9} \cdot 8 \mathrm{H}_{2} \mathrm{O}$ \\
\hline 18. & kernite & $\mathrm{Na}_{2} \mathrm{~B}_{4} \mathrm{O}_{7} \cdot 4 \mathrm{H}_{2} \mathrm{O}$ & \\
\hline 19. & pinnoite & $\mathrm{Mg}\left(\mathrm{BO}_{2}\right)_{2} \cdot 3 \mathrm{H}_{2} \mathrm{O}$ & $\mathrm{MgH}_{6} \mathrm{~B}_{2} \mathrm{O}_{7}$ \\
\hline 20. & boron oxide & $\mathrm{B}_{2} \mathrm{O}_{3}$ & $\mathrm{~B}_{2} \mathrm{O}_{3}$ \\
\hline
\end{tabular}

* After F.A. Miller and C.H. Wilkins. ${ }^{11}$ $\mathrm{b}=$ broad $\mathrm{Sh}=$ Shoulder 
260 Infrared Absorption and Structures of Borate Polyatomic Ions

$\begin{array}{lcc}\text { Bond } & \begin{array}{c}\text { Difference of } \\ \text { electron negativity }\end{array} & \begin{array}{c}\text { Amount of } \\ \text { ionic character }\end{array} \\ \mathrm{B}-\mathrm{O} & 1.5 & 43 \% \\ \mathrm{Si}-\mathrm{O} & 1.7 & 53 \%\end{array}$

The value of ionic character found for $\mathrm{B}-\mathrm{O}$ bonds is indeed close to that of $\mathrm{H}-\mathrm{O}$ bonds, the ionic character of $\mathrm{H}-\mathrm{O}$ bonds being estimated as $39 \%$, and $\mathrm{B}-\mathrm{O}-\mathrm{B}$ angles in borate groups will have more significant meaning than $\mathrm{Si}-\mathrm{O}-\mathrm{Si}$ bond angles.

Table 3. Bond angle for oxygen in borate groups.

\begin{tabular}{c|c|c}
\hline $\begin{array}{c}\text { Fundamental linkage } \\
\text { of borate groug }\end{array}$ & $\begin{array}{c}\text { Polyatumic } \\
\text { ion }\end{array}$ & $\begin{array}{c}\text { B-O-B } \\
\text { angle }\end{array}$ \\
\hline & $\begin{array}{l}\left(\mathrm{B}_{2} \mathrm{O}_{5}\right) \text { group } \\
\text { (in suanite) } \\
\left(\mathrm{B}_{5} \mathrm{O}_{10}\right) \text { group } \\
\left(\mathrm{B}_{3} \mathrm{O}_{6}\right) \text { group } \\
\left(\mathrm{B}_{2} \mathrm{O}_{4}\right) \text { chain }\end{array}$ & $\begin{array}{l}131.5^{\circ} \\
127^{\circ} \\
126.5^{\circ} \\
130^{\circ} 13^{\prime}\end{array}$ \\
\hline \\
\hline 0
\end{tabular}

Actually, the angles found by X-ray analysis in various borate polyatomic ions appear to have constant values for each fundamental linkage of borate groups (Table 3). Namely, for oxygen atom between two triangles, the angles are close ${ }^{*}$ to the theoretical $\mathrm{O} \leqslant$ angle, $125^{\circ} 16^{\prime}$. These observed bond angles are, however, larger than the theoretical one by about $4 \%$. This may be due to in the main the steric effects of $\mathrm{BO}_{3}$ groups. For the case where the oxygen atom connects two $\mathrm{BO}_{4}$ tetrahedra, the angles are very close to $109^{\circ} 28^{\prime}$ which is ex-

* The $\mathrm{B}-\mathrm{O}-\mathrm{B}$ bond angle of $153^{\circ}$ found in $\mathrm{Co}_{2} \mathrm{~B}_{2} \mathrm{O}_{5}$ is exceptional.2' 
pected for $\mathrm{O}<$ bond angle. The angle for the oxygen atom of $\left(\mathrm{B}_{2} \mathrm{O}_{7}\right)$ group found in pinnoite is markedly small. However, the value is less accurate because the structure of pinnoite was determined on the basis of the pseudo space group, $\mathrm{P} 4_{2} / n$, inspite of the evidence that the true space group of the mineral is $\mathrm{P}_{2} / \mathrm{m}$. The real value of the bond angle might be closer to the tetrahedral bond angle. Although the final atomic parameters of colemanite and meyerhofferite have not been appeared, the similar bond angles are expected in the $\left(\mathrm{B}_{2} \mathrm{O}_{7}\right)$ structural units in both the $\left(\mathrm{B}_{3} \mathrm{O}_{8}\right)$ group of meyerhofferite and the $\left(\mathrm{B}_{3} \mathrm{O}_{7}\right)$ chain of colemanite.

It is interesting to note that in the hybrid configuration where the oxygen atom is shared by a $\mathrm{BO}_{3}$ triangle and a $\mathrm{BO}_{4}$ tetrahedron, the bond angle for the oxygen atom takes the value in between of the other two cases discussed above.

It thus appears that the bonds between boron and oxygen are so strong and rigid that the oxygen bond angles found for the $\left(\mathrm{B}_{2} \mathrm{O}_{5}\right)$ group in suanite and the $\left(\mathrm{B}_{2} \mathrm{O}_{7}\right)$ group in pinnoite are always maintained in more complicated borate polyatomic ions which contain these groups as part of their polyatomic ions whatever the rest of the structures may be like.

These fundamental boron-oxygen groups are shown in Fig. 10.

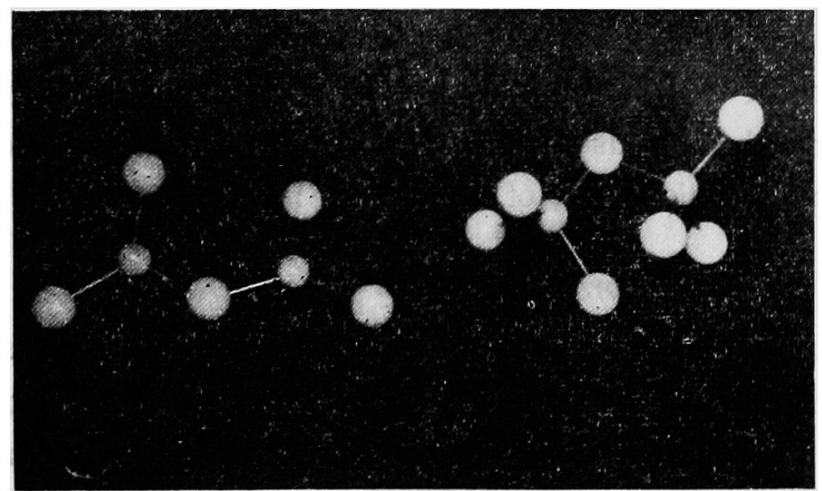

(a)

(b)

Fig. 10 Fundamental configurations of boron-oxogen arrangements.

(a) $\mathrm{B}_{2} \mathrm{O}_{5}$ group as found in suanite.

(b) $\mathrm{B}_{2} \mathrm{O}_{7}$ group as found in pinnoite. 
Other forms of separate boron-oxygen groups which have so far been found are shown in Fig. 11 where the $\left(\mathrm{B}_{2} \mathrm{O}_{5}\right)$ and $\left(\mathrm{B}_{2} \mathrm{O}_{7}\right)$ groups are indicated by thick lines for each group. Shapes of these two groups are also well preserved in boron-oxygen chains such as $\left(\mathrm{B}_{2} \mathrm{O}_{4}\right)$ and $\left(\mathrm{B}_{3} \mathrm{O}_{7}\right)$ which are shown in Flg. 12 .

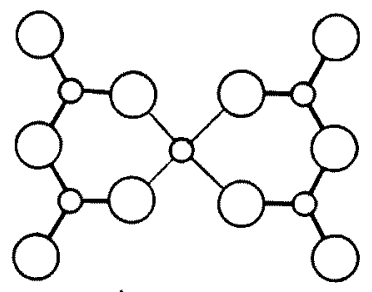

$\left(\mathrm{B}_{5} \mathrm{O}_{10}\right)$

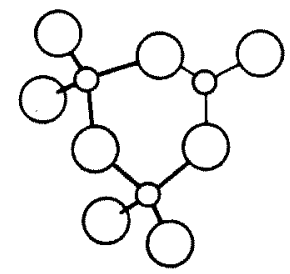

$\left(\mathrm{B}_{3} \mathrm{O}_{8}\right)$

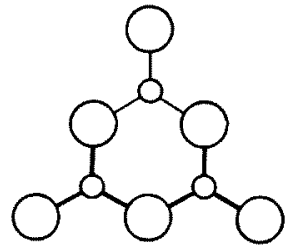

$\left(\mathrm{B}_{3} \mathrm{O}_{6}\right)$

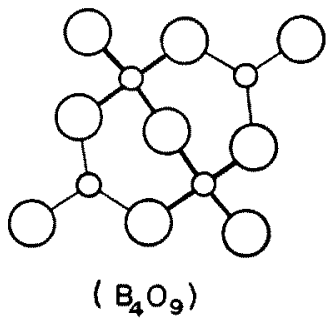

Fig. 11 Forms of separate boron-oxygen groups.

$\mathrm{B}_{2} \mathrm{O}_{5}$ and $\mathrm{B}_{2} \mathrm{O}_{7}$ groups are indicated by thick lines.

In many borate polyatomic ions, oxygen may be replaced to a certain extent by hydroxyl. The description of boron-oxygen arrangements through out this paper must therefore be taken to cover cases where partial replacement of oxygen by hydroxyl occurs.

Coordination of the boron atom.

Boron has been found at the center of either a tetrahedral group of four oxygen atoms or three oxygen atoms at corners of an equilateral triangle. The bond distances which have been found in three fold groups vary from 1.32 to $1.40 \AA$, and those in tetrahedral groups are around $1.47 \AA$ ( $1.41 \AA$ as found for $\mathrm{BO}_{4}$ group in teepleite5) and $1.56 \AA$ in $\left(\mathrm{B}_{2} \mathrm{O}_{2}\right)$ group of pinnoite13) are the two extremes). 

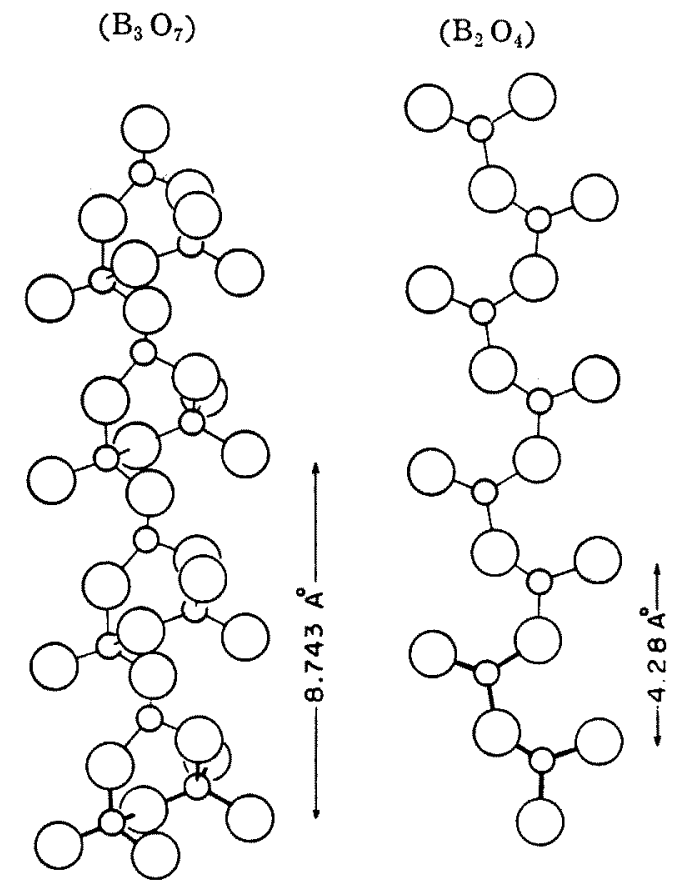

Fig. 12 Forms of boron-oxygen chains, $\mathrm{B}_{2} \mathrm{O}_{5}$ and $\mathrm{B}_{2} \mathrm{O}_{7}$ groups are indicated by thick lines.

As the shapes of these two groups are always regular, we must assume an intermediate state of the $\mathrm{B}-\mathrm{O}$ bonding for the coordination of boron in boron oxide1). The $\mathrm{B}-\mathrm{O}$ configuration in the boron-oxygen network of the crystal is observed to be of non-coplanar triangle with the $\mathrm{B}-\mathrm{O}$ distances $1.48,1.48$ and $1.37 \AA$, the boron beeing placed $0.44 \AA$ apart from the plane of this triangle. The boron atom is coordinated by another oxygen atom with the distance of $2.14_{5} \AA$ and thus the coordination of the atom has been described as a highly distorted tetrahedron of four oxygen atoms.

A similar acute oxygen pyramid with a boron inside and near the basal plane has been found in the boron-oxygen network of boracite ${ }^{10}$ ) in which the distance between boron and oxygen at the apex of the pyramid is calculated as $1.78 \AA$. This kind of boron coordination is shown in Fig. $13 \mathrm{c}$. 


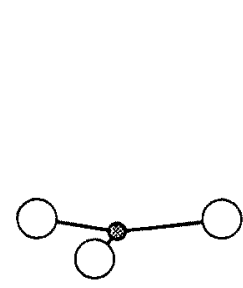

(a)

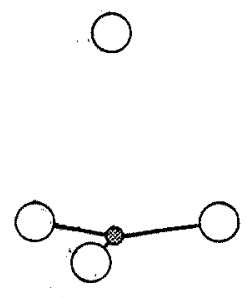

(b)

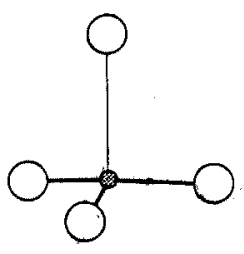

(c)

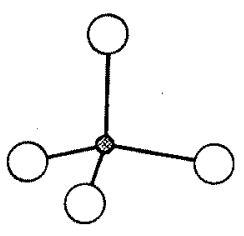

(d)

Fig. 13 Various coordinations of boron atoms.

Except separarte $\mathrm{BO}_{3}$ groups in orthoborates, the coplanar $\mathrm{BO}_{3}$ groups as a constituent element of a polyatomic ions also appear to have a tendency to form, with another oxygen atom, a very acute oxygen pyramid (Fig. $13 \mathrm{~b}$ ). The distances between boron and the fourth oxygen atoms found in various borates are listed as follows.

Crystal

boric acid*241

calcium metaborate ${ }^{251}$

borax $^{1.21}$

suanite ${ }^{18}$

sodium metaboratei ${ }^{i 5}$

potassium metaborate ${ }^{21}$
Distance between oxygen at the apex of acute pyramid and boron in the basal plane.

potassium acid dihydronium pentaborate ${ }^{22}$

$\{3.157 \AA$

$\{3.184$

3.10

2.99

3.11

$3-23$

3.67

3.83

* The structure of boric acid may be regarded as composed of $\mathrm{H}_{3} \mathrm{BO}_{3}$ sheets rather than of separte $\mathrm{BO}_{3}$ groups.

It is interesting to note that, in such structures where the octahedral oxygen groups with metal atoms (say magnesium) inside form endless chain, the $\mathrm{BO}_{3}$ groups and $\left(\mathrm{B}_{2} \mathrm{O}_{5}\right)$ groups arrange themselves in different ways; e.g., in ludwigite, the planes of $\mathrm{BO}_{3}$ groups are at right angle to the chains, while, in suanite, the effective planes of the $\left(\mathrm{B}_{2} \mathrm{O}_{5}\right)$ groups are inclined to the chains so that an oxygen in one $\left(\mathrm{B}_{2} \mathrm{O}_{5}\right)$ group forms an acute oxygen pyramid with a $\mathrm{BO}_{3}$ group which is the constituent element of another $\left(\mathrm{B}_{2} \mathrm{O}_{5}\right)$ group (Fig. 14).

Classification of borate polyatomic ions.

As shown in the previous paragraph, the classification of borate 


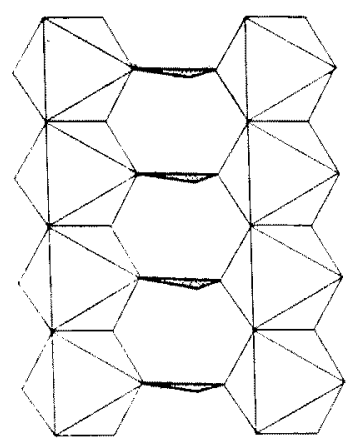

(0)

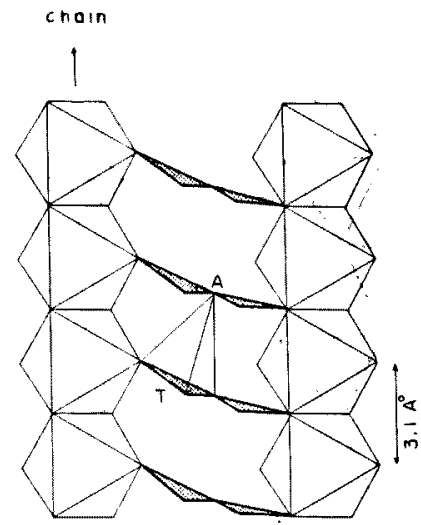

(b)

Fig. 14 Comparison of arrangement of $\mathrm{BO}_{3}$ groups in ludwigite (a) and that of $\mathrm{B}_{2} \mathrm{O}_{5}$ groups in suanite (b) where one acute oxygen pyramid formed by oxygen, $\mathrm{A}$, and triangle, $\mathrm{T}$, is shown.

polyatomic ions may rest on the three structural types; i.e. types with triangular-, tetrahedral- and hybrid configurations. Another way of classification will be made on the bassis of the configurations of the polyatomic ions as a whole, and the types of the ions thus classified will be 'separate group', 'chain', 'network' and perhaps 'sheet'

However, it is also possible to classify them by the number of constituent tetrahedra and triangles in the boron-oxygen groups or in the asymmetric unit of infinite groups. The borate polyatomic ions summarized in Table 4 are classified in these ways.

The $\left(\mathrm{B}_{3} \mathrm{O}_{6}\right)$ chain, mono-tetrahedral di-triangular borate chain, is the one found in monoclinic metaboric acid, $\mathrm{HBO}_{-}^{23)}$. This chain structure also presents an example which well supports the discussion on the nature of $\mathrm{B}-\mathrm{O}$ bond as given above because the asymmetric unit of the chain consists of a $\left(\mathrm{B}_{2} \mathrm{O}_{5}\right)$ group and a $\mathrm{BO}_{4}$ tetrahedron. Although the detail account on the structure has not been reported, the chain structure may be schematically shown as given in Fig. 15 where it is compared with the other two borate chains. 


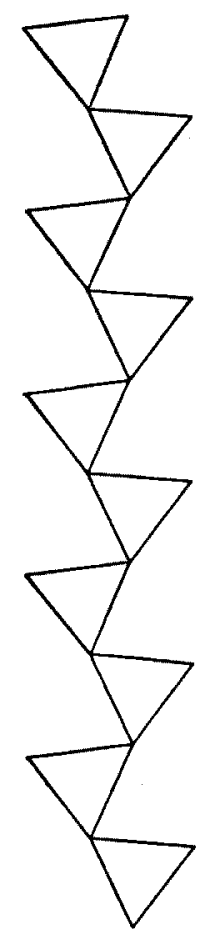

(a)

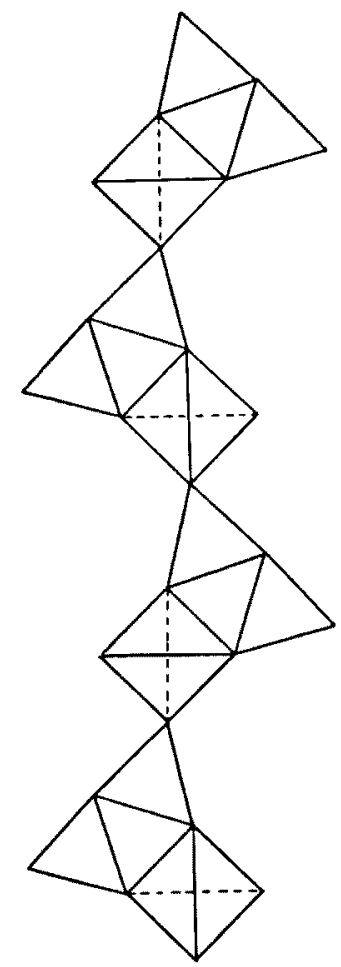

(b)

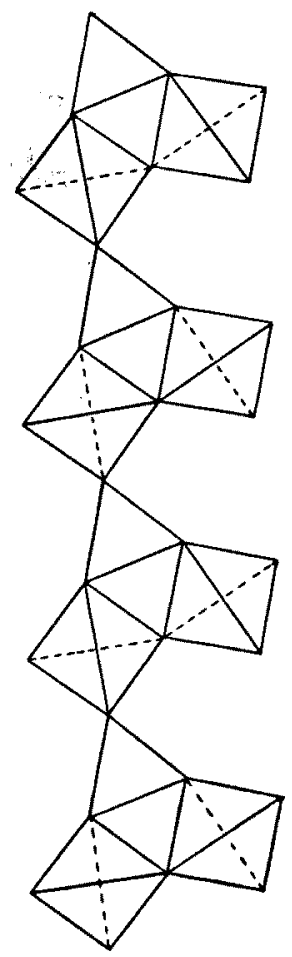

(c)

Fig. 15. A schematical presentation of boron-oxygen chains.
(a) $\mathrm{B}_{2} \mathrm{O}_{4}$
(b) $\mathrm{B}_{3} \mathrm{O}_{6}$
(c) $\mathrm{B}_{3} \mathrm{O}_{7}$

Table 4. Classification of borate polyatomic ions.

\begin{tabular}{|c|c|c|c|c|c|}
\hline $\begin{array}{l}\text { No. of } \\
\text { tetrahedron }\end{array}$ & $\begin{array}{l}\text { No. of } \\
\text { triangle }\end{array}$ & $\begin{array}{c}\text { Separate } \\
\text { group }\end{array}$ & chain & network & sheet \\
\hline \multirow{4}{*}{0} & 1 & $\underset{\text { kotoite }}{\mathrm{BO}_{3}}$ & & & \\
\hline & 2 & $\underset{\text { suanite }}{\mathrm{B}_{2} \mathrm{O}_{5}}$ & $\begin{array}{c}\mathrm{B}_{2} \mathrm{O}_{4} \\
\text { calcium } \\
\text { metaborare }\end{array}$ & & * \\
\hline & 3 & $\begin{array}{c}\mathrm{B}_{3} \mathrm{O}_{6} \\
\text { potassium } \\
\text { metaborate }\end{array}$ & & & * \\
\hline & 4 & & & & \\
\hline
\end{tabular}




\begin{tabular}{|c|c|c|c|c|c|}
\hline \multirow{5}{*}{1} & 0 & $\begin{array}{c}\mathrm{BO}_{4} \\
\text { teepleite }\end{array}$ & & & $\%$ \\
\hline & 1 & & & & $\psi^{*}$ \\
\hline & 2 & & $\begin{array}{c}\mathrm{B}_{3} \mathrm{O}_{6} \\
\text { metaboric } \\
\text { acid }\end{array}$ & & $\psi^{*}$ \\
\hline & 3 & & & & $\| *$ \\
\hline & 4 & $\begin{array}{c}\mathrm{B}_{5} \mathrm{O}_{10} \\
\text { potassium acid } \\
\text { dihydronium } \\
\text { pentaborate } \\
\end{array}$ & & & $\psi^{*}$ \\
\hline \multirow{4}{*}{2} & 0 & $\begin{array}{c}\mathrm{B}_{2} \mathrm{O}_{7} \\
\text { pinnoite }\end{array}$ & & $\mid \begin{array}{c}\mathrm{B}_{2} \mathrm{O}_{3} \\
\text { boron oxide }\end{array}$ & $*$ \\
\hline & 1 & $\begin{array}{c}\mathrm{B}_{3} \mathrm{O}_{8} \\
\text { meyerhofferite }\end{array}$ & $\begin{array}{l}\mathrm{B}_{3} \mathrm{O}_{7} \\
\text { colemanite }\end{array}$ & & $\% *$ \\
\hline & 2 & $\begin{array}{l}\mathrm{B}_{4} \mathrm{O}_{9} \\
\text { borax }\end{array}$ & & & $\psi *$ \\
\hline & 3 & & & & $\because *$ \\
\hline \multirow{3}{*}{3} & 0 & & & & $\varphi^{\circ}$ \\
\hline & 1 & & & & $\because *$ \\
\hline & 2 & & & & $\because *$ \\
\hline \multirow{2}{*}{4} & 0 & & & & $\because$ \\
\hline & 1 & & & & $\because *$ \\
\hline 5 & 0 & & & $\begin{array}{c}\mathrm{B}_{5} \mathrm{O}_{12} \\
\text { boracite }\end{array}$ & " \\
\hline
\end{tabular}

* Triangular configuration.

$\because$ Tetrahedral configuration.

\%* Hybrid configuration.

\section{Acknowledgements}

I am indebted to Professor T. Ito and Dr. R. Sadanaga for helpful 
discussions. Special acknowledgement is due to Dr. K. Ichishima of the Chemical Institute for discussions and various facilities for the present experiments. Thanks are also due to Professor T. Watanabé for furnishing materials, to Professor R. Kiriyama, Osaka University, and to Mr. Y. Iitaka for valuable comments.

\section{REFERENCES}

1) Berger, S.V.; Acta Chem. Scand., 7, 611 (1953).

2) Berger, S.V.: Acta Chem. Scand., 4, 1054 (1950).

3) Christ, C. L., Joan R. Clark and H. T. Evans JR ; Acta Cryst., 7, 453, (1954).

4) Christ, C. L. and Joan R. Clark: Acta Cryst., 9, 830, (1956).

5) Fornaseri, M.; Perio. Mineral., 18, 103, (1949).

6) Frondel, C., V. Morgan and J.L.T. Waugh; Am. Mineral., 41, 927, (1956).

7) Horning D.F. and R.C. Plumb; J. Chem. Phys., 26, 637 (1957).

8) Hunt, J.M., M.P. Wisherd and L.C. Bonham; Anal. Chem. 22, 1478, $(1950)$.

9) Ito, T.; X-Ray Studies on Polymorphism. Tokyo: Maruzen, (1950).

10) Ito, T., N. Morimoto and R. Sadanaga: Acta Cryst., 4, 310, (1951).

11) Miller, A.F. and C.H. Wilkins: Anal. Chem., 24. 1253, (1952).

12) Morimoto, N.: Mineralogical Journal, 2, 1. (1956).

13) Paton, F. and S.G.G. MacDonald,: Acta Cryst., 10, 653, (1957).

14) Steele, W.C. and J.C. Decius: J. Chem. Phys., 25, 1184, (1956).

15) Ssu-Mien Fang: Z. Krist., 99, 1. (1938).

16) Takéuchi, Y.: Mineralogical Journal, 2, 78, (1957).

17) - Acta Cryst., 3, 208, (1950).

18) - Acta Cryst., 5, 574, (1952).

19) . T. Ito ond T. Watanabé: Acta Cryst., 3, 98, (1950).

20) ; Mineralogical Journal, 2, 19, (1956).

21) Zachariasen, W.H.: Chem. Phys,, 5, 919, (1937).

22) - Z. Krist., 98, 266, (1937).

23) - : Acta Cryst., 5, 68, (1952).

24) - ; Acta Cryst., 7, 305, (1954).

25) - and G.E. Ziegler: Z. Krist., 93, 354, (1932).

Manuscript received April, 20, 1958. 